\title{
Flora Differentiation among Local Ecotopes in the Transzonal Study of Forest-Steppe and Steppe Mounds
}

\author{
F. N. Lisetskii ${ }^{a}$, B. Sudnik-Wojcikowska ${ }^{b}$, and I. I. Moysiyenko ${ }^{c}$ \\ ${ }^{a}$ Belgorod State National Research University, ul. Pobedy 85, Belgorod, 308015 Russia \\ ${ }^{b}$ University of Warsaw, Krakowskie Przedmiescie 26/28, 00-927 Warsaw, Poland \\ ${ }^{c}$ Kherson State University, ul. 40 Let Oktyabrya 27, Kherson, 73000 Ukraine \\ e-mail: liset@bsu.edu.ru \\ Received January 20, 2015
}

\begin{abstract}
Flora similarity was assessed using complete floristic lists of five ecotopes in each of four mounds along the transect from meadow steppes to desert steppes. It was found that the circumapical similitude of floras is more significant than the expositional similitude. Soil analysis in separate ecotopes showed that regular changes in the biogeochemical features are manifested along the topographic gradient and under the effect of the insolation exposure of slopes in local (mound) ecosystems. It was noted that the slopes are characterized by the most abundant steppe vegetation classes in the phytosociological spectrum of mound ecotopes.
\end{abstract}

DOI: $10.1134 / \mathrm{S} 1062359016010106$

\section{INTRODUCTION}

The landscapes of the virgin steppe are dominated by mounds. The first investigators of the steppe noted this singular feature: "They [mounds] are located separately or in groups of two or three; sometimes, they form a regular chain stretching away" (Dilevskaya, 1905, p. 6). Ruprekht (1866), a Russian botanist, who noted the presence of $\sim 800$ mounds near the city of Chernigov and analyzed the results of their excavation, was one of the first scientists emphasizing the scientific importance of the soil and plant cover on mounds, which was earlier ignored in archeological excavations. Ruprekht (1866, p. 9) referred to the opinion of Blasius (1844) that the soil cover of mounds results from the activity of local plants. Recent integrated scientific studies of mounds have been made by Hungarian (Barczi, 2003; Joó et al., 2007; Toth et al., 2014), Ukrainian (Moysiyenko and SudnikWójcikowska, 2006), Polish (Rowińska et al., 2010; Sudnik-Wójcikowska and Moysiyenko, 2012), Russian (Kuksova, 2011; Demkin et al., 2014; Lisetskii et al., 2014), and international teams.

The generalization of the results obtained reveals the potential of mounds as unreproducible natural ecosystem models for studying a wide range of scientific problems. The primary questions are the topological zonation in the distributions of soils and biota; soil-climate relationships (on the meso- and microlevels); chronosequences of soils and vegetation; biogeochemical series along the topographic gradient; dependences of secondary successions on the type of habitat; mounds in the context of steppe relics, ecological niches, source habitat, refugia, and genetic changes in isolates; and the use of heterochronous proofs of soil memory for paleobotanical and paleosol studies.

The mound flora mainly consisting of aboriginal steppe species and sozophytes is comparative in volume and conservation value to that of reserved areas in the steppe zone, which determines the role of mounds as refugia of steppe flora (Sudnik-Wójcikowska and Moysiyenko, 2012). The spatial and temporal organization of biogeochemical cycles in the combined consideration of bio- and pedodiversity is still poorly understood (Beare et al., 1995).

The aim of this study was a coupled study of plant species distribution and related soil properties among separate mound ecotopes arranged in a transzonal series of local ecosystems.

\section{MATERIALS AND METHODS}

From the results of preliminary studies of 106 mounds $>4 \mathrm{~m}$ in height, for which the typicality of the plant cover was rated from the presence of steppe flora and vegetation elements, especially sod grasses of the genera Stipa, Festuca, and Koeleria (SudnikWójcikowska and Moysiyenko, 2012), the most representative objects of study in the transzonal series were determined. They represent well-preserved burial mounds $6-7.5 \mathrm{~m}$ in height located under different climatic conditions in the forest-steppe and steppe zones of the East European Plain (Lavrenko et al., 1991 ) in the Cherkassk (F), Nikolaev (R), and Kherson (P, D) districts of Ukraine (Fig. 1). Because of the different macroclimatic conditions, the mounds are 


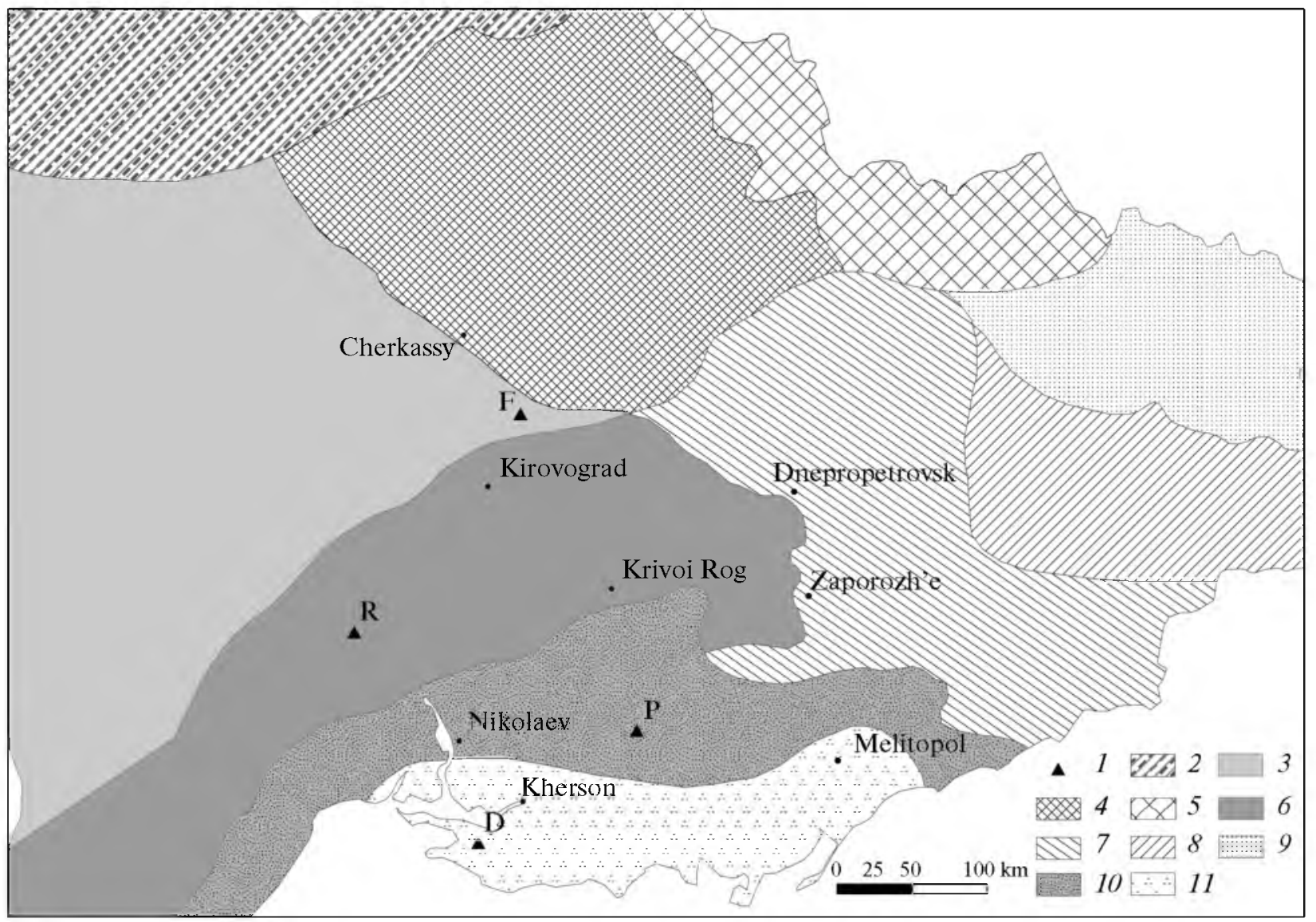

Fig. 1. Location of the key objects of study (mounds in forest-steppe and steppe) on the physicogeographical zonation sketch map: (1) mounds (F, R, P, D); (2) Polesie province (coniferous-broad-leaved zone). Forest-steppe zone: (3) Dniester-Dnieper forest-steppe province; (4) Dnieper left bank forest-steppe province; (5) Central Russian forest-steppe province. Steppe zone (northern steppe subzone): (6) Dniester-Dnieper northern steppe province; (7) Dnieper left bank-Azov northern steppe province; $(8)$ Donets northern steppe province; (9) Donets-Don northern steppe province. (10) Black Sea medium steppe province (medium steppe subzone). (11) Black Sea-Azov dry steppe province (dry steppe zone).

characterized by specific flora compositions, pedogenesis processes, and renaturation potentials. The background vegetation includes meadow $(F)$, herb and herb-grass (R), grass (P), and deserted (D) steppes. The climatic conditions become more xeromorphic along the transzonal gradient (the meridional distance from $F$ to D is $296 \mathrm{~km}$ ), because the annual values of atmospheric precipitation significantly decrease $(F, 527 ; \mathrm{R}, 440 ; \mathrm{P}, 380 ; \mathrm{D}, 370 \mathrm{~mm})$; the mean January temperature decreases by $2.7^{\circ} \mathrm{C}$, and the mean January temperature increases by $2.1^{\circ} \mathrm{C}$. For the most geographically remote objects, the background climate parameters, which are generalized in the energy equivalent of pedogenesis (Volobuev, 1985), vary by 1.2 times, from $1078(\mathrm{~F})$ to $872 \mathrm{MJ} /\left(\mathrm{m}^{2}\right.$ year $)$ (D), and the calculated values of annual plant production vary by 1.8 times, from 12.5 (F) to $7.1 \mathrm{t} / \mathrm{ha}(\mathrm{D})$.

The plant cover of the mounds was studied using floristic lists for each of the five ecotopes: the top (t), the southern and northern slopes (ss, sn), and the southern and northern bases (bs, bn). To obtain the complete fioristic list, measurements were performed in spring, summer, and fall. The occurrence of species was estimated using a three-mark scale: (3) common, (2) sporadic, and (1) rare. The procedure of study was described in detail earlier (Sudnik-Wojcikowska and Moysiyenko, 2012). The degree of flora similarity in separate ecotopes was determined by comparing the floristic lists using the complete sample method, Statistica 6.0 software, and Pearson's procedure. Cluster analysis included the use of the 1-Pearson metric. Particular features of flora in ecotopes were revealed by comparing the spectra of life forms and phytosociological groups. The macro- and microelements in ecotope soils were determined on a Spectroscan MaxGV X-ray fluorescent element analyzer. To improve the reliability, the calibration on soil standards was performed in several replicates. 


\section{RESULTS AND DISCUSSION}

The plant cover on most of the well-preserved mounds (usually the highest of them, $18-20 \mathrm{~m}$ in height) developed over $15-45$ centuries. The high mounds, as well as those studied by our team, were never plowed. They are surrounded by agrolandscapes and represent insular ecosystems, which inherited floristic features of primary communities and have specific soil covers. The study of mound soils in the steppe zone showed that they are slightly more xeromorphic, as is their vegetation, than the background soils on flat areas (Ivanov, 1992).

The earth mound structures erected by ancient humans allowed the vegetation of the plakor steppe to use various ecological niches in vertical microzones, the analogues of which were more dispersed in the plain areas.

To determine the zonal representativeness of mound flora, Moysiyenko et al. (2014) compared the mound flora in the grass steppe zone (in our work, mound $P$ ) with three reserved objects located in the same zone: the Askania-Nova Biosphere Reserve, the Yakovlevskii Botanic Reserve, and the projected Lessovyi Kanion Landscape Reserve. The great sozological importance of the mounds was established, because the structure of mound flora is similar to that of the reference steppe plots located within the reserved areas. In particular, the similar proportions of plant species were revealed on the mound and within the reserved areas: 56 and $46-60 \%$ for the steppe species, 39 and $39-48 \%$ for the nonsynanthropic species, and 5 and $6 \%$ for the rare species, respectively.

For the Scythian burial mounds of kings and court officials in the 6th-3rd centuries BC (usually up to $7 \mathrm{~m}$ high), blocks of sod (i.e., the upper 8- to $10-\mathrm{cm}$ thick soil layer) were usually used (Lisetskii et al., 2011). The starting conditions for the initial communities of mound flora were mostly determined by the seed and bulb bank, which contained transplants. The phytolithic analysis of samples from the bulk material of the Scythian mound Chertomlyk (Klamm et al., 1991) clearly showed that the erection of a $20-\mathrm{m}$ high mound required excavating a $\sim 20-\mathrm{cm}$ thick humusaccumulative layer of chernozem from an adjacent area of $\sim 35$ ha to cut sod blocks. A high initial zoogenic activity can also be supposed; in most cases, this is the leading factor determining the destruction rate and transformation character of organic matter in the soil (Striganova, 2009), as well as the role of pedobionts, which was undoubtedly one of the leading readaptation factors for the applicative evolution of soils.

The floristic list of the mounds includes 307 vascular plants species (42.6\% of the Ukrainian mound flora for the 106 objects studied earlier) from 195 genera and 51 species. The leading flora families include Asteraceae, Poaceae, Brassicaceae, Fabaceae, Caryophyllaceae, Lamiaceae, and Scrophulariaceae. Achil- lea, Artemisia, Carex, Elytrigia, Euphobia, Galium, Polygonum, Trifolium, Verbascum, Veronica, and Vicia are the most polymorphic genera. In the ecological spectra, submesophytes and subxerophytes are the dominant groups related to edaphotope moisture conditions; heminitrophils and subnitrophils are the prevalent groups related to soil trophicity; heliophytes and subgeliophytes are the major groups related to edaphotope illumination. The important environmental role of mounds is confirmed by the significant proportions of nonsynanthrophic (43\%), steppe (57.7\%), and preserved $(4.6 \%)$ plant species.

The analysis of floristic lists (containing 307 species distributed among the mound habitats) using Pearson's procedure revealed their regular distribution among the geographical clusters (Fig. 2). First, mound flora is subdivided into two groups conventionally called northern steppes and southern steppes. The northern steppes include phytocenoses of the zone of herb-grass and rich herb-grass steppes, as well as steppe communities of the forest-steppe. The isolated location of the mounds and their construction features favored the formation of a xerophytic steppe plant cover, which explains the similarity of floras of the mounds in the forest-steppe zone and those in the northern steppe zone. The floras of the mounds in the grass and deserted steppes are conventionally aggregated into the group of southern steppes.

The analysis performed revealed regularities in the flora distribution among the separate ecotopes. The feet of the mounds are most distinctly separated from the mound slopes and tops. The mound tops are separated on a lower clustering level. The floras of the northern and southern mound slopes are most similar; i.e., the circumapical similitude of floras is more significant than the expositional similitude. This tendency is typical for the three natural zones. A deviation is observed only for the forest-steppe mounds: the floras of the feet and the northern slope are most similar; the mound top and the southern slope are combined in another floristic group. The floristic lists of separate ecotopes differ not only in qualitative and quantitative characteristics, but also in the ecological-phynocenotic parameters. A clear tendency of increasing species richness when going from the tops to the feet of mounds is observed in all cases. The most important reason for the species composition of the feet is their radical difference in hydrothermal conditions from the other ecotopes. Along with the steppe communities, this ecotope also includes meadow and shrub species (Amygdalus nana, Prunus stepposa, Rhamnus catharticus, Sambucus nigra); the presence of phanerophytes, which are almost completely absent in other ecotopes, in the spectra of life forms is most indicative (Fig. 3).

A sliding migration of landscape microzones is observed in the superposition of the zonal trend, i.e., a general decrease in wetting along the $\mathrm{F}-\mathrm{D}$ transect 


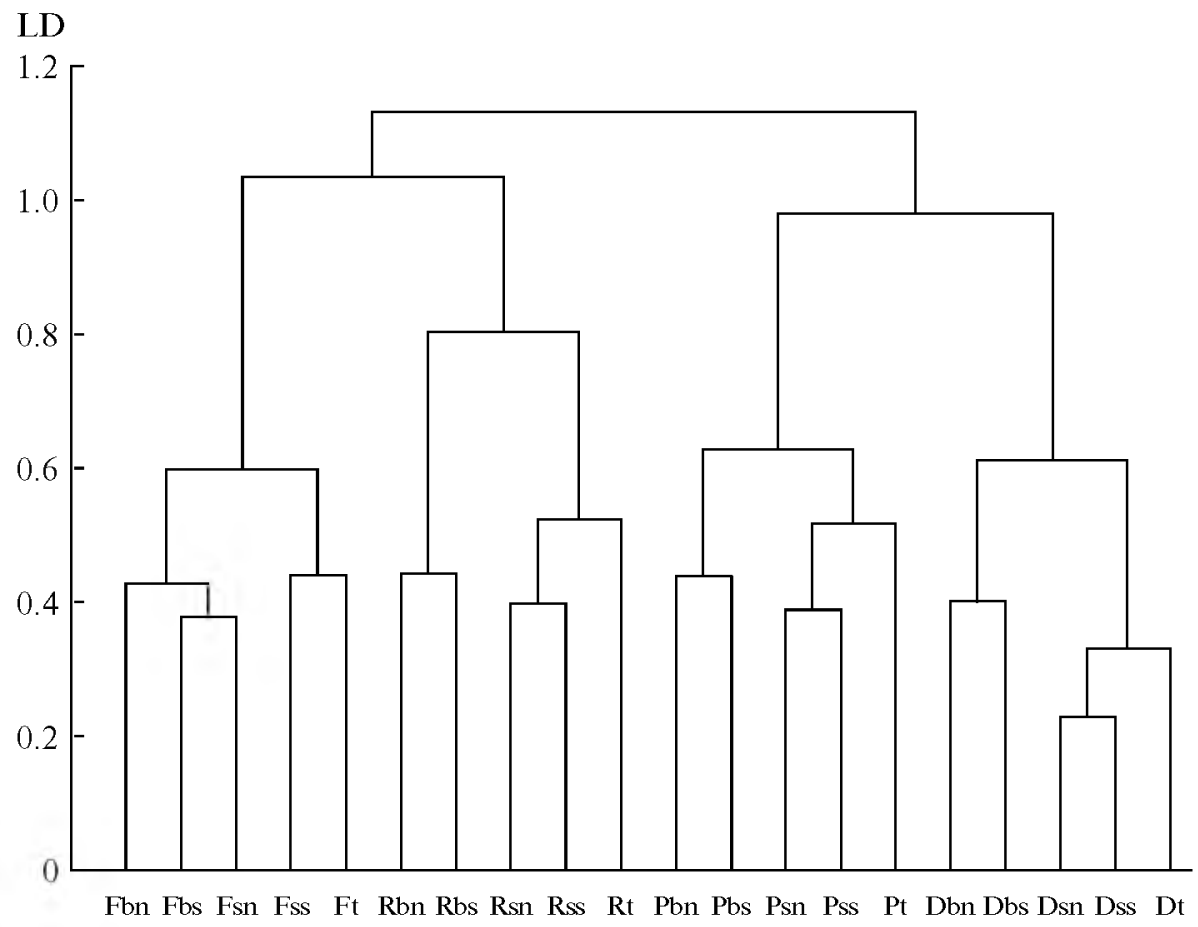

Fig. 2. Results of the cluster analysis of flora in different ecotopes of mounds (F, R, P, D): (t) top; (sn, ss) northern and southern exposures in the middle part of slopes, respectively; (bn, bs) feet of the northern and southern slopes, respectively. For Figs. 2 and 3 , the ordinate axis shows the distance of association (LD).

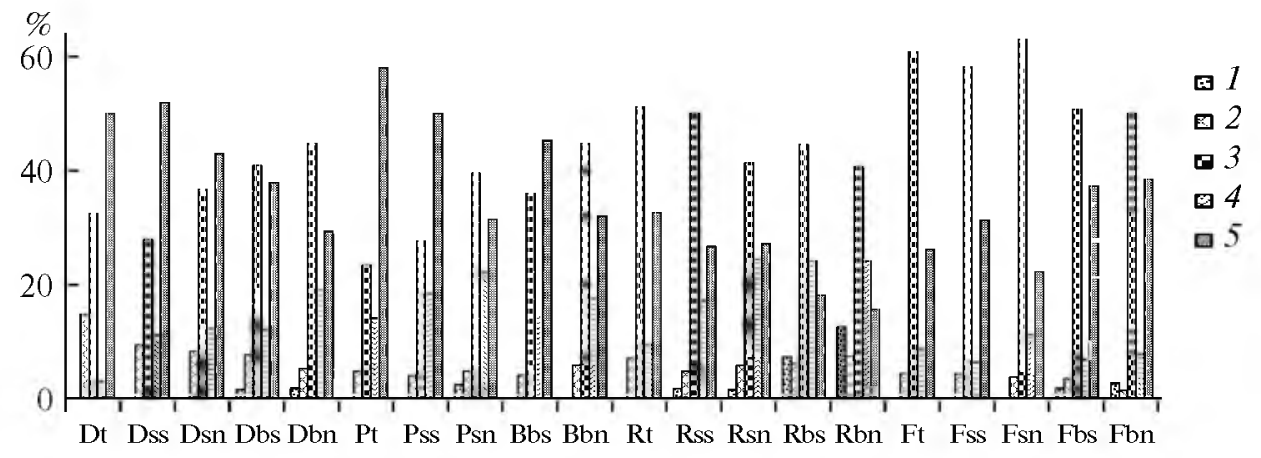

Fig. 3. Distribution of life forms (\%) in different habitats of mounds (F, R, P, D). Life forms: ( 1 ) micro- and nanophanerophytes; (2) hamephytes and hemicryptophytes-hamephytes; (3) hemicryptophytes; (4) geophytes and geophytes-hemicryptophytes; (5) therophytes and short-leaved perennials.

with the increase in moisture content from the top to the foot of the mound within the catena (Bokov, 1983).

Among all the ecotopes, hemicryptophytes are the most common life forms in all of the studied mounds; therophytes and biennial and perennial monocarps are slightly inferior. The mound catena feet have some specific features: their proportions of geophytes, geophytes-hemicryptophytes, and phanerophythes increase with a simultaneous decrease in the proportion of hamephytes.

The mound located in the Black Sea-Azov drysteppe province (D) appreciably differs from all the other studied objects by the significant predominance of therophytes and short-leaved perennials ( $42 \%$ compared to $33 \%$ on the other three mounds). This is related to the fact that the zone of wormwood steppe occupies an intermediate position between the steppes and the semideserts, where the proportion of therophytes in the floral spectrum can reach $70 \%$. In addition, synanthropization is related to sheep breeding, which has been developed there until recently, and therophytes are the prevailing anthropophytes.

A specific feature of phytosociological groups is the relatively high proportion of species in the MolinioArrhenatheretea group, including Galietalia veri, and an insignificant but almost exclusive presence of woodyshrub plants (classes Querco-Fagetea, Rhamno-Pru- 
netea, and Robinietea). The ecological specificity of this ecotope is manifested in the increasing proportion of submesophytes and mesophytes in the spectrum of hydromorphs, nitrophils in the spectrum of nitromorphs, and subheliophytes in the spectrum of heliomorphs. The proportion of halophytic species in the phytocenotic spectrum of mound feet in the dry-steppe subzone is appreciable.

The most separate group of ecotopes includes the slopes and the top; it is characterized by the lowest species richness. Plants of the class Festuco-Brometea and Stellarietea mediae are most common among the phytosociological groups. In ecological terms, xerophilic, low-nitrogen tolerant, and light-demanding plants are typical for the automorphic positions.

The Artemisio-Kochion Soo 1959 communities (Festuco-Brometea) develop on the tops, which frequently descend to the southern slopes in the southern steppe. Phytocenoses of the alliances of Festucion valesiacae Klika, 1931 and Astragalo-Stipion Knapp, 1944 prevail on slopes but sometimes penetrate to the top (especially in the north) and foot (especially in the south).

The more favorable and diverse conditions on the feet favor the growth of not only steppe plants, but also meadow, shrub, and even some forest plants, which are more exigent to microclimate and soil fertility conditions; therefore, the significant isolation of this group of habitats is noted in all of the objects studied. The mound feet are occupied by communities of meadow steppes (alliances Cirsio-Brachypodion pinnati Fladac et Kilka, 1994; Krausch, 1961 and Fragario viridis-Trifolion montani Korotchenko et Didukh, 1997), and those of stepped meadows from the order Galietalia veri Mirk. et Naum., 1986 (Molinio-Arrhenatheretea). Some shrub species (Amygdalus nana, Plantago stepposa, Rhamnus catharticus, Sambucus nigra) and woody species (Acer negundo, Armeniaca vulgaris, Elaeagnus angustifolia, Fraxinus penssylavanica) are detected at the feet of the four mounds under study. These groups, especially in the steppe zone, frequently rise up the mound slopes.

The slopes represent the largest ecotope of the mounds. Their conditions are more favorable than those on the tops, but inferior to those at the feet. In the spectrum of life forms, hemicryptophytes prevail in the north and therophytes prevail in the south. The role of geophytes increases simultaneously (Fig. 3). The slope ecotope is the most steppelike mound ecotope; its phytosociological spectrum includes the maximum proportions of steppe plant classes (Festuco-Brometea and Festucetalia vaginatea). On the slopes of all four mounds, only a small number of steppe species occur in all natural zones (subzones): Achillea setacea, Otites densiflorum, Phlomis pungens, Verbascum phoeniceum, and Euhorbia virgata. The mound occurring in the forest-steppe $(F)$ is characterized by the highest diversity of steppe flora within the slope ecotope (Hyacinthella leu., Allium, Achillea,
Euphorbia, Astragalus, Gagea, Limonium, and Veronica species).

The specificity of the slopes is determined by the significant participation of xerophytes and perxerophytes in the spectrum of hygromorphs, subantithrophyles in the spectrum of azotomorphs, and heliophytes in the spectrum of heliomorps. The northern and southern slopes vary slightly compared to the other ecotopes (Pearson's coefficients are 0.22-0.4). Significant differences are observed between the slopes of different exposures only in the forest-steppe. The northern slope has more favorable conditions for plants, which affects the number of species and increases the role of more mesophytic, sciophytic, and nitrophilic plants.

On the mounds, a soil and plant cover develops along the topographic gradient over a relatively long time, which corresponds to the microlandscape conditions of the ecotopes: tops, slopes of different exposures, and feet. The attainment of the climax state in the plant community is determined by the ecosystem component with the highest characteristic time: the edaphotope (Lisetskii, 1998). Therefore, it is important to estimate the degree of maturity of plant communities and soils, which were differently restored in separate mound ecotopes during the period after mound construction. The diversity of mound phytocenoses depends on the differences in the hydrothermal conditions and soil properties of the ecotopes. The development of soils is mutually related to the development of plants; it depends on the hydrothermal and geochemical processes causing the differentiation of landscape conditions along the transect under natural conditions and on the old artificial earthwork structures (Lisetskii, 1999).

From the results of the bulk analysis of soils from the upper $(0-$ to $24-\mathrm{cm})$ horizons, the relative coefficients of biogeochemical enrichment in the rhizosphere zones of separate ecotopes were calculated using the classification of plant nutrients into three groups (Bityutskii, 2011): useful nutrients, essential macronutrients, and essential micronutrients (table). The top ecotope was used as the reference, because its pedogenesis conditions were most similar to the automorphic conditions. The low nutrient supply of plants in the ecotope of the middle southern slope should be noted as a stable feature typical for all mounds. This is primarily due to the lower contents of essential macroand micronutrients in the soils of this ecotope than in the soils at the mound feet.

The generalized analysis of ecotopes by cluster analysis (Lisetskii et al., 2014) showed that the totality of the agro- and geochemical characteristics of soil properties ( 26 parameters) of ecotopes sn and bs has a general tendency: the mounds located in the grass $(P)$ and desert (D) steppe zones are most similar, and the mounds in the meadow (F) and herb-grass (R) steppe zones are most different. This tendency is also manifested at the assessment of soil conditions from the 
Ratios of the sums of essential macro- and micronutrients and useful nutrients in soils of different ecotopes with respect to the soils of mound tops

\begin{tabular}{|c|c|c|c|c|}
\hline \multirow[b]{2}{*}{ Mound } & \multirow[b]{2}{*}{ Ecotope } & \multicolumn{3}{|c|}{ Plant nutrients } \\
\hline & & $\mathrm{K}+\mathrm{Mg}+\mathrm{Ca}$ & $\begin{array}{c}\mathrm{Mn}+\mathrm{Fe}+\mathrm{Ni}+ \\
\mathrm{Cu}+\mathrm{Zn}\end{array}$ & $\mathrm{Si}+\mathrm{Al}$ \\
\hline \multirow[t]{5}{*}{$\mathrm{F}$} & $\mathrm{t}$ & 1 & 1 & 1 \\
\hline & sn & 1.27 & 1.03 & 0.89 \\
\hline & bn & 0.63 & 1.18 & 0.96 \\
\hline & ss & 0.98 & 1.09 & 0.91 \\
\hline & bs & 0.76 & 0.96 & 0.93 \\
\hline \multirow[t]{5}{*}{$\mathrm{R}$} & $\mathrm{t}$ & 1 & 1 & 1 \\
\hline & $\operatorname{sn}$ & 0.98 & 0.3 & 0.98 \\
\hline & bn & 1.06 & 0.31 & 0.99 \\
\hline & ss & 1.05 & 0.33 & 0.97 \\
\hline & bs & 1 & 0.3 & 0.97 \\
\hline \multirow[t]{5}{*}{$\mathbf{P}$} & $\mathrm{t}$ & 1 & 1 & 1 \\
\hline & sn & 0.59 & 0.9 & 1.07 \\
\hline & bn & 0.58 & 1.03 & 1.06 \\
\hline & Ss & 0.95 & 0.91 & 1.06 \\
\hline & bs & 0.59 & 0.78 & 1.1 \\
\hline \multirow[t]{5}{*}{$\mathrm{D}$} & $\mathrm{t}$ & 1 & 1 & 1 \\
\hline & sn & 1.33 & 0.97 & 0.94 \\
\hline & bn & 0.99 & 1.2 & 1.01 \\
\hline & ss & 0.9 & 0.93 & 0.96 \\
\hline & bs & 0.81 & 0.7 & 0.98 \\
\hline
\end{tabular}

(F, R, P, D) mounds; (t) top; (sn, ss) northern and southern exposures in the middle part of slopes, respectively; (bn, bs) feet of the northern and southern slopes, respectively.

contents of 10 mineral nutrients consumed for the growth of plant organs.

The average values of three coefficients were calculated from the sums of the necessary macro- and micronutrients and useful nutrients in different ecotopes relative to the mound tops (table), and the following ordered series of ecotopes was determined: sn $(0.94)<$ bn $=$ ss $(0.92)<$ bs $(0.82)$. It can be seen that the upper horizons of soils in the middle part of the northern slope are most enriched with nutrients, compared to the mound tops, in the extreme members of the transzonale mound series: in the forest-steppe (F) and the desert steppe (D), mainly due to the high contents of essential macroenutrients ( $\mathrm{Ca}$ and $\mathrm{Mg}$ ).

The differences in the intensity of the biogenic accumulation of plant nutrients (table) depended on the transformation rates of plant material and leaching under the effect of specific hydrothermal conditions in separate types of ecotopes, as well as the conditions of element fixation in the organomineral complexes of soils.
The joint study of the soil and plant covers of the mounds revealed the main tendencies in the syngenetic development of steppe ecosystems in different ecotopes with specific features of the zonal environment.

The processing of data by statistical methods revealed a specific feature of soil differentiation, which is not detected in the separation of flora: this is ecotope exchange between the mounds located in different zones, namely, the desert and grass steppes. According to the soil analyses, the northern slope and the foot of the mound located in the desert steppe were placed in the same group with the four ecotopes of the grasssteppe zone. The southern foot of the mound located in the grass steppe, on the contrary, was placed in the group with the three resting ecotopes of the mound located in the desert-steppe zone. The Alekhin preceding rule (Alekhin, 1924) is confirmed in this case.

With consideration for the preceding studies, we revealed 721 vascular plant species on the 106 mounds that were studied thoroughly (26 in the desert steppe zone, 26 in the grass subzone, 29 in the herb- and rich herb-grass subzones of true steppes, and 25 in the meadow steppes of the forest-steppe) (SudnikWójcikowska and Moysiyenko, 2012). The detected plants included 549 native species $(76.1 \%), 332$ nonsynanthropic species (46.1\%), and 341 steppe species (i.e., having the phytocenotic optimum in the class Festuco-Brometea and some close syntaxons: Festucetalia vaginatae, Galietalia veri, and Polygono-Artemisietea) (47.3\%). The average number of species per mound in separate natural zones and subzones varied from 82 to 125 (Sudnilc-Wójcikowska and Moysiyenko, 2012), which averaged $15 \%$ of the total number of species in the corresponding surroundings. The largest numbers of species were found in the families Asteraceae, Poaceae, and Fabaceae, which generally also prevail in the flora of Ukraine. The highest species diversity was typical for the genera Veronica (18 species), Trifolium (12 species), Astragalus (11 species), Euphorbia (10 species), Potentilla (10 species), and Centaurea ( 9 species). The genera Achillea, Artemisia, Carex, Galium, and Viciau included eight species each; the genera Viola, Allium, and Salvia included seven species each. The four mounds studied in this work include the following interesting sozophytes: Stipa lessingiana Trin. and Rupr., S. capillata L., Adonis vernalis L., Amygdalus nana L., Anchusa pseudo-ochroleuca Des.-Shost., Crocus reticulatus Steven ex Adams, Elytrigia stipifolia (Czern. ex Nevski) Nevski, Eremogone rigida (M. Bieb.) Fenzl, Galium volhynicum Pobed., Hesperis tristis L., Hyacinthella leucophaea (K. Koch) Schur, Limonium platyphyllum Lincz., Ranunculus scythicus Klokov, and Seseli tortuosum L.

\section{CONCLUSIONS}

The joint effect of the zonal trend (a general decrease in wetting along the $\mathrm{F}-\mathrm{D}$ transect) and the 
catenary increase in the content of moisture from the top to the floor of the mound explains the fact that the ecotopes F (ss) and D (bs) of the most remote objects (F and D) are characterized by a common feature of the hydrological regime of soils: better wetting. This is confirmed by the higher coefficients of eluviation with respect to the corresponding mound tops and other ecotopes.

The maximum accumulation of essential plant nutrients in the soil of the biogeochemical association is generally observed on the northern slopes and at their feet, as well as on the mound tops, although to a lesser extent (not without the anthropogenic factor). The differences in the soil-plant relationships, which are determined by the change in environmental conditions along the topographic gradient, create a stable differentiation in the intensity of biological turnover in the mound microzones, which determines peculiar trends in the evolution of soil and plant cover on the polar slopes.

Individual trajectories of developments are realized in separate ecotopes of the mounds because of the significant differences in the age (maturity) of soils and plants. The most favorable conditions for the permanent combination and recombination of species in the community always develop on the southern slopes.

The mound-slope ecotope, which includes 18$33 \%$ of the total number of species (307), is characterized by the maximum representation of the steppe plant classes in the phytosociological spectrum. Therefore, the habitats on the mound slopes contain the most valuable genetic and cenotic fund of flora, which can be used for the ecological restoration of zonal steppe vegetation in the autonomous positions.

The environmental value of the mound flora, which contains significant proportions of aboriginal, nonsynanthropic, and steppe species and sozophytes, is quite comparable with that of the floras of reserved steppe areas. The revealed flora species on the mounds of southern Ukraine include $69(9.6 \%)$ sozophyte species (protected, rare, engendered, or included in red books of different levels). As some species are included in several lists, sozophytes occupy 96 positions in these lists.

The large-scale economic development of ecosystems in the steppe zone and the imperative need for the optimization of the land fund structure will require the high potential (genetic and cenotic fund) of mound flora for the realization of efficient programs of steppe restoration. Therefore, a new integrated approach is necessary for assessing the importance of such objects of historical and cultural heritage as the mounds, whose soil and plant cover is usually irreparably destroyed by archeological excavations.

\section{ACKNOWLEDGMENTS}

The work was done in the framework of the implementation of the base part of the state assignment of the Ministry of Education and Science of the Russian Federation for the Belgorod State National Research University in the activity type "Organization of scientific research" (2014/420-1).

\section{REFERENCES}

Alekhin, V.V., Complexes and construction of ecological association series, Byul. MOIP, 1924, vol. 32, nos. 1-2, pp. 99-111.

Barczi, A., Data for the botanical and pedological surveys of the Hungarian kurgans (Great Hungarian Plain, Hortobagy), Thaiszia J. Bot., 2003, vol. 13, pp. 113-126.

Beare, M.H., Coleman, D.C., Crossley, D.A., Jr., Hendrix, P.F., and Odum, E.P., A hierarchical approach to evaluating the significance of soil biodiversity to biogeochemical cycling, The Significance and Regulation of Soil Biodiversity, Ser. Dev. Plant Soil Sci., 1995, vol. 63, pp. 5-22.

Bityutskii, N.P., Mikroelementy vysshikh rastenii (Trace Elements of Higher Plants), St. Petersburg: Izd. SPbGU, 2011.

Blasius, J.H., Reise im europaisehen Russland in den Jahren 1840 und 1841. Ister Theil. Reise im Norden. Braunsehw, 1844.

Bokov, V.A., Prostranstvenno-vremennaya organizatsiya geosistem (Spatiotemporal Organization of Geosystems), Simferopol': Izd. Simferopol. Univ, 1983.

Demkin, V.A., Klepikov, V.M., Udaltsov, S.N., Demkina, T.S., Eltsov, M.V., and Khomutova, T.E., New aspects of natural science studies of archaeological burial monuments (kurgans) in the southern Russian steppes, J. Archaeol. Sci., 2014, vol. 42, no. 1, pp. 241-249.

Dilevskaya, N., Chernomorskie stepi (Black Sea Steppes), Moscow, 1905.

Ivanov, I.V., Evolyutsiya pochv stepnoi zony v golotsene (Evolution of Soils of the Steppe Zone in the Holocene), Moscow: Nauka, 1992.

Joó, K., Barczi, A., and Sümegi, P., Study of soil scientific, layer scientific and palaeoecological relations of the Csipömound kurgan, Atti della Soc. Toscana Sci. Nat., Memorie, Ser. $A, 2007$, no. 112, pp. 141-144.

Klamm, M., Fibrok, G., and Meyer, B., Pedological studies of Scythian burial kurgan Chertomlyk, in Chertomlyk, Tolochko, P.P., Ed., Kiev: Nauk. dumka, 1991, pp. 286306.

Kuksova, M.A., Kurgans-refugia of steppe vegetation biodiversity in agricultural landscapes of the south of Russia, Vestn. Mosk. Gos. Obl. Univ., Ser. Estestv. Nauki, 2011, no. 1, pp. 34-37.

Lavrenko, E.M., Karamysheva, Z.V., and Nikulina, R.I., Stepi Evrazii (Steppes of Eurasia), Leningrad: Nauka, 1991.

Lisetskii, F.N., Autogenic succession of steppe vegetation in postantique landscapes, Russ. J. Ecol., 1998, vol. 29, no. 4, pp. 217-219.

Lisetskii, F.N., Soil catenas in archeological landscapes, Eurasian Soil Sci., 1999, vol. 32, no. 10, pp. 1084-1093.

Lisetskii, F.N., Chernyavskikh, V.I., and Degtyar', O.V., Pastures in the zone of temperate climate: trends for development, dynamics, ecological fundamentals of rational use, in Pastures: Dynamics, Economics and Management, Procházka, N.T., Ed., New York: Nova Sci. Publ. Inc., 2011, pp. 51-83. 


\section{LISETSKII et al.}

Lisetskii, F.N., Goleusov, P.V., Moysiyenko, I.I., and Sudnik-Wójcikowska, B., Microzonal distribution of soils and plants along the catenas of mound structures, Contem. Probl. Ecol., 2014, vol. 7, no. 3, pp. 282-293.

Moysiyenko, I. and Sudnik-Wójcikowska, B., The flora of kurgans in the steppe zone of Southern Ukraine-phytogeographical and ecological aspects, Polish Bot. Studies, 2006 , no. 22, pp. 387-398.

Moysiyenko, I., Zachwatowicz, M., Sudnik-Wójcikowska, B., and Jabłońska, E., Kurgans help to protect endangered steppe species in the Pontic grass steppe zone, Ukraine, Wulfenia, 2014, vol. 21, pp. 83-94.

Rowińska, A., Sudnik-Wójcikowska, B., and Moysiyenko, I.I., Kurhany-dziedzictwo kultury w krajobrazie antropogenicznym strefy stepów i lasostepu - oczami archeologa i botanika, Wiadomości Bot., 2010, vol. 54, nos. 3-4, pp. 7-20.
Ruprekht, F., Geobotanicheskie issledovaniya o chernozeme (Geobotanical Study of Black Soil), St. Petersburg, 1866.

Striganova, B.R., Spatial distribution of the animal population of soil in climatic gradients, Usp. Sovrem. Biol., 2009, vol. 129 , no. 6 , pp. 538-549.

Sudnik-Wójcikowska, B. and Moysiyenko, I.I., Kurhany na "Dzikich Polach"- dziedzictwo kultury i ostorja ukrainskiego stepu, Warszawa: Wydawnictwa Uniw. Warszawsk., 2012.

Toth, C.A., Pethe, M., and Hathazi, A., The application of earth science-based analyses on a twin-kurgan in northern Hungary, Carpathian J. Earth Environ. Sci., 2014, vol. 9, no. 1, pp. 11-20.

Volobuev, V.R., On the biological component of the energy of soil, Pochvovedenie, 1985, no. 9, pp. 5-8.

Translated by K. Pankratova 